\title{
Integration of Glyphosates and Hand Weeding for Weeds Management in Maize (Zea mays. L)
}

\author{
Megersa Kebede*, Gudeta Bedada and Fufa Anbasa \\ Oromia Agricultural Research Institute, Bako Agricultural Research Center, Ethiopia \\ Submission: August 16, 2018, Published: December 05, 2018 \\ *Corresponding author: Megersa Kebede, Oromia Agricultural Research Institute, Bako Agricultural Research Center, Bako, Ethiopia
}

\begin{abstract}
A field experiment was carried out at Bako agricultural research center during 2016/2017 main season.to investigate efficiency of integrated options against weeds in maize field. It was laid-out in randomized complete block design with three replications. Treatments included, Weed knock at 2 lt ha- ${ }^{-1}$ hand weeding at (HW@) 40 DAS, Herbazed at 2 lt ha ${ }^{-1}+$ HW@ 40 DAS, Round-up 36 SL at 2 lt ha ${ }^{-1}+$ HW@ 40 DAS, and two times hand weeding at 25 DAS and 40 DAS along with weedy plots. Accordingly, all treatments were significantly increased grain yield of maize there by reducing infestation of weeds. Of integrated options, Round-up 36 SL at 2 lt ha ${ }^{-1}+$ HW@ 40 DAS recorded the minimum $\left(11.27 \mathrm{~m}^{-2}\right)$ total density of weeds after 80 DAS. In contrary, the maximum $\left(71.60 \mathrm{~m}^{-2}\right)$ density was counted from weedy plots. Herbazed at 2 lt ha- ${ }^{-1}+$ HW@ 40 DAS provided the minimum total fresh $\left(64.79 \mathrm{gm}^{-2}\right)$ and dry $\left(12.30 \mathrm{gm}^{-2}\right)$ weight of weeds after 80 DAS which was statistically the same with other treatments; whereas the maximum total fresh and dry weight of 3991.30 and $523.70 \mathrm{gm}^{-2}$.was from weedy plots, respectively. Weed knock at $2 \mathrm{lt}$ ha $^{-1}$ + HW@ 40 DAS provided the highest grain yield (58.13qt ha ${ }^{-1}$ ) with $33.00 \%$ yield advantage over weedy check having statistical similarity with other treatments. The lowest (38.95qt ha-1) yield obtained from weedy plots. Thus, integrated weed management options boosted maize grain yield providing efficient control of weeds.
\end{abstract}

Keywords: Integration; Maize productivity; Weeds

Abbreviations: HW: Hand Weeding; IWM: Integrated Weed Management; RCBD: Randomized Complete Block Design; PWI: Percentage of weed inhibition; YL: Yield Loss

\section{Introduction}

Maize (Zea mays L.) is a very important agricultural crop and among the three most widely grown in the world [1]. Maize is widely cultivated throughout the world between latitudes $50^{\circ}$ north and south of the equator and from sea level to $3600 \mathrm{~m}$ elevation, in cool and hot weathers, with variable growing cycles [2]. In Ethiopia, maize is an important crop because of its high productivity per unit area, suitability to major agro-ecologies and compatibility with many cropping systems [3]. It has increasingly become a popular crop in the country with steady growth in production area and yield [4]. Maize is consumed as food and also used as animal feed, particularly for poultry. It is primarily produced and consumed by the small-scale farmers that comprise about $80 \%$ of Ethiopia's population [5]. In this country, the national average maize yield in 2014 was 3.4 ton per hectare [6]. The wide gap in yields is due to a wide range of production constraints among which weeds share the major biotic agents.

Maize crop is usually heavily fertilized and sparsely grown, both of these situations attracts a sever weed infestation that result in drastic reduction in grain yield during early stage [7]. In Ethiopia, Some report of yield losses in maize due to weeds range between 20 to $100 \%$ [8]. In western part of the country particularly; due to warm and humid climatic condition different weed species grow quickly and causing significant yield losses [9]. Therefore, maize fields should be kept weed free.

Various management options are used to control weeds in maize fields. Among these, Herbicides are the most efficient and available weed management tools and that weed management is most successful and economical when the all necessarily practices for weed control are utilized in an integrated fashion. Herbicide use is increasing in many countries where tillage and flooding for weed control are being reduced in order to conserve natural resources: soil, water and energy. Soil disturbance is considered an important factor in breaking dormancy and might explain lower weed densities under no-tillage compared to the other tillage systems [10]. Weeds controlled by herbicides instead of conventional tillage, stored soil water are increased by $85 \mathrm{~mm}$ in Africa [11]. In no-till or minimum till maize production, herbicides may be required to control or suppress emerged weeds. Research demonstrated that using herbicides instead of tillage resulted in $27 \mathrm{~mm}$ of extra water in the soil profile and an increase in grain yields of $15-25 \%$ [12].

Glyphosate is non-selective herbicide that is applied prior to maize planting for annual and perennial weed control in reduced tillage situations and will kill emerged weeds [13]. However, these 
herbicides have no residual action for long time in the growing season and lately emerged weed species can compete with crop. Hence, supplementation of these herbicides with hand weeding or any other compatible management practices is mandatory to reduce competition due lately emerged weeds. In addition to this, according to [14], due to its widespread and repeated use, 13 weed species in the USA have evolved resistance to glyphosate and 23 species worldwide by 2012 . However, most companies are not developing any new selective herbicides with new modes of action that can be effective for the control of glyphosate- resistant weeds [15].

In Ethiopia, Round-up 36 SL (Glyphosate 360g/l) is the most common glyphosate class herbicide that has been used for many years since its recommendation. This situation may lead to development of resistance in weed species. Additionally, in western parts of the country there is heavy rainfall that encourages the continuous weed emergence, growth and development which in turn cause high infestation and competition of weeds to maize crop in the areas and calls to look for effective control option like integrated weed management (IWM). Integrated weed management (IWM) involves a combination of cultural, mechanical, biological, genetic, and chemical methods for an effective and economical weed control that reduces weed interference with the crop while maintaining acceptable crop yields $[16,17]$. None of the individual control measures can provide complete weed control. However, if various components of integrated weed management are implemented in a systematic manner, significant advances in weed control technology can be achieved [18].

Keeping this in view, involving integrated weed management is a need to minimize resistance development and the yield losses due to weed competition. Realizing this, the field trial was initiated to evaluate the effect of combination of hand weeding with pre-planting non-selective herbicides for the control annual and perennial broad leaves and grasses weeds on no-till land preplant maize field at the study area.

\section{Materials and Methods}

\section{Study areas}

A field experiment was conducted at Bako Agricultural Research Center on station during main cropping season of 2016/17. It is found in the Western part of Oromia with about $133 \mathrm{~km}$ from Ambo, the capital town of West Shoa zone and $260 \mathrm{~km}$ from Fin fine, the capital city of the country. It is located

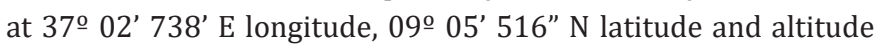
of $1635 \mathrm{~m}$.a.s.l. The soil is sandy in texture. It has a warm-humid climate with annual mean minimum and maximum temperature of $13.6{ }^{\circ} \mathrm{C}$ and $29.1{ }^{\circ} \mathrm{C}$, respectively and receives average annual rainfall of $1264 \mathrm{~mm}$.

\section{Treatments detail and field lay-out}

The experiment consisted of five (5) treatments. Three of them were non-selective post-emergence herbicides each supplemented with one times hand hoeing and weeding at 40 days after sowing (40 DAS) i.e. Weed knock (Glyphosate 360G/L SL) at $2 \mathrm{lt} \mathrm{ha}^{-1}+$ One times hand weeding at 40 DAS, Herbazed (Glyphosate) at $2 \mathrm{lt} \mathrm{ha}^{-1}+$ One times hand weeding at 40 DAS, Round-up 36 SL (Glyphosate $360 \mathrm{~g} / \mathrm{l}$ ) at $2 \mathrm{lt} \mathrm{ha}^{-1}+$ One times hand weeding at 40 DAS. Whereas the remaining treatments; two times hand weeding and Weedy check (control) were used for comparisons. The name of herbicides mentioned in brackets are the chemical name whereas the preliminary (out-side brackets) is the trade names. The trial was established with Randomized Complete Block Design (RCBD) having three replications.

\section{Crop husbandry and herbicides application}

Improved hybrid maize variety "BH-546" seed was used as a test variety and planted at $18^{\text {th }}$ days after herbicide applied on $8 \mathrm{~m}$ x $8 \mathrm{~m}$ plot area by 75 and $30 \mathrm{~cm}$ spacing between rows and plants, respectively. Herbicides were emulsified in $200 \mathrm{lt} \mathrm{ha}^{-1}$ water and applied once before planting using 20 liters knapsack sprayer. All plots sprayed with herbicides were supplemented by one-time hand hoeing and weeding at 40 days after sowing (40 DAS). Hand weeded plots were weeded two times at $25^{\text {th }}$ and 40 days after planting where weed check plots kept un-treated throughout growing season. All other agronomic practices were kept uniform i.e., as per area recommendation for all plots.

\section{Data collection and management}

Various data were collected from both weed and maize crop parameters. Weed infestation was assessed and scored by number and species throwing quadrant of $50 \mathrm{~cm} \times 50 \mathrm{~cm}$ area three times per plot at 80 days after sowing (80 DAS) using method described by [19]. The counted weeds were separated in to species as broad and grass weed species. Percentage of weed inhibition (PWI) was calculated by the formula of:

Percentage of weed inhibition $(P W I)=\left(\frac{N W C-N W T}{N W C}\right) * 100$

Where, NWC \&NWT are number of weeds $\left(\mathrm{m}^{-2}\right)$ in weedy check and any particular treatment, respectively.

The collected weeds were first sun dried and weighted specieswise. The dry weight of each species was taken by an electrical balance and expressed in gm $^{-2}$. Weed control efficiency (WCE) was calculated using the following formula developed by [20];

$$
\text { Weed control efficacy }(W C E)=\left(\frac{W D C-W D T}{W D C}\right) * 100 \ldots \ldots \ldots(\text { Eqn. } 2)
$$

Where, WDC \& WDT are weed dry weight $\left(\mathrm{gm}^{-2}\right)$ in control and any particular treatment, respectively.

\section{Maize crop data like}

Plant height (cm), number of cob per plant, number of rows/ cob, number of kernel/row, above ground biomass (kg/plot), 1000 seed weight (gm), moisture content (\%) were recorded from ten (10) sampled plants per plots, and stand count at harvest and field weight (kg/ plot) were recorded from the whole harvestable rows at different maize crop growth stage. Finally, grain yield was expressed in hectare and yield loss of the crop due to weed infestation was assessed with the manipulation of the yield obtained from maximum protected plot with yield of lower 
treatments. Hence, the relative percent grain yield loss (YL) was calculated using formula:

$$
\text { Grain yield } \operatorname{loss}(Y L \%)=\left(\frac{Y b t-Y l t}{Y b t}\right) * 100 \ldots \ldots \ldots \ldots . \text { Eqn.3 }
$$

Where, Ybt is the yield from maximum protected plot and Ylt is the yield from lower treatments, yields from weedy check.

\section{Data analysis}

The collected data were analyzed using GenStat Statistical package was used for the data analysis and significance test and means were separated using LSD at $p<0.05$. All weed data were transformed before analysis, using the square-root transformation formula $\sqrt{ }(x+0.5)$.

\section{Results and Discussion}

\section{Weed flora composition}

Different weed compositions have been observed in experimental fields. The recorded data regarding to weed flora demonstrated that, associated weeds in experimental plots were categorized as broad leaved and grasses. The broad leaved contributed to higher percentage $(81.8 \%)$ of totally noticed weeds. Whereas, grass weeds shared lower percentage (18.2\%). A totally of eleven (11) weed species classified under six (6) families were observed. Among these species Bidens pachyloma, Galinsoga parviflora, Guzotia scarba and Cynodon dactylon and Elusina indica were found under the family of Gramineae, Celosia argentea and Caylusea abyssinica (Amaranthaceae), Commelina species (Commelinaceae), Nicandra physalodes (Solanaceae) and Stellaria media was found under (Caryophyllaceae).

Gramineae and Compositae contains the maximum number of species three (3) and contributed to the highest percentage
(27.3\%) each. Guzotia scarba, Elusina indica, Stellaria media and Galinsoga parviflora species were the most important species to the area. This is in analogy with the findings of [9], who reported twelve weed species belonging to five families are appeared to infest the experimental maize crop field.

\section{Weed density $\left(\mathrm{m}^{-2}\right)$}

Analysis of the variance indicated that broad leaf and total weed density was significantly affected $(p<0.001)$ whereas grass weeds affected $(\mathrm{p}<0.01)$ by treatments application at 80 days after sowing (80 DAS) (Table 1) below. Integration of herbicides with on-time hand weeding at 40 days after sowing (40 DAS) had considerable effect on weeds and reduced their population to a significant level as compared to weedy check. Significantly the maximum total weed density $\left(71.60 \mathrm{~m}^{-2}\right)$ was obtained from weedy check plots. In contrary, the minimum density $\left(11.27 \mathrm{~m}^{-2}\right)$ was from Round-up $36 \mathrm{SL}+$ One times hand weeded at 40 DAS, followed by Weedknock + One times hand weeded at 40 DAS $\left(12.47 \mathrm{~m}^{-2}\right)$. This might be due to the fact that applied herbicides provided effective control on all early emerged weeds and supplementation with one-time hand weeding at 40 DAS clears the lately emerged one mechanically by hoeing and hand pulling there by reduced the overall population of weeds in plots. These results are in analogy with $[21,22]$. They reported that weed control methods like application of herbicides and hand weeding significantly decreased weed density. Duraisamy Ravisankar et al. [18]; [23] also reported that post-emergence application of glyphosate at different rates in transgenic maize hybrids recorded with lower weed density and higher weed control efficiency compared to other treatments. There was no significance difference observed among combined treatments and/or two times hand weeded plots for weed densities. However, numerical difference was noticed.

Table 1: Weed density $\left(\mathrm{m}^{-2}\right)$ as influenced by different weed management practices at 80 DAS at Bako, 2016.

\begin{tabular}{|c|c|c|c|c|}
\hline \multirow{2}{*}{ Treatments } & \multicolumn{4}{|c|}{ Weed Density $\left(\mathrm{m}^{-2}\right)$} \\
\hline & Broad Leaf & Grass Leaf & Total Weed & PWR \% \\
\hline Weedknock (2L/ha) + HW@40DAS & $4.3 \pm 2.1 \mathrm{a}$ & $2.0 \pm 1.4 \mathrm{a}$ & $12.5 \pm 3.5 \mathrm{a}$ & 82.12 \\
\hline Herbazed (2L/ha) + HW@40DAS & $5.2 \pm 2.3 \mathrm{a}$ & $1.1 \pm 1.0 \mathrm{a}$ & $12.7 \pm 3.3 \mathrm{a}$ & 82.06 \\
\hline Round-up (2L/ha) + HW@40DAS & $4.6 \pm 2.1 \mathrm{a}$ & $1.1 \pm 1.0 \mathrm{a}$ & $11.3 \pm 3.2 \mathrm{a}$ & 83.7 \\
\hline Hand Weeded (2x) & $5.4 \pm 2.3 \mathrm{a}$ & $3.5 \pm 1.8 \mathrm{a}$ & $17.9 \pm 4.1 \mathrm{a}$ & 75.04 \\
\hline Weedy Check & $26.6 \pm 5.2 b$ & $9.2 \pm 3.0 \mathrm{~b}$ & $71.6 \pm 8.1 b$ & ------ \\
\hline $\mathrm{Cv}(\%)$ & 6.3 & 15.4 & 10.4 & \\
\hline F-test $(5 \%)$ & $* *$ & $*$ & $* *$ & \\
\hline
\end{tabular}

Means followed by the same letter within the column are not significantly different at $p<0.05$ using LSD.

Note: ${ }^{* *},{ }^{*}=$ significance difference at $(\mathrm{p}<0.01)$ and $(\mathrm{P}<0.05)$ respectively; $\mathrm{ns}=$ no significance difference; CV $(\%)=\mathrm{Cofficient}$ of variation; F-test $(5 \%)=$ Probability value; Weedknock = Glyphosate 360G/L SL; Herbazed = Glyphosate; Round-up 36 SL = Glyphosate 360g/l; PWR\% = Percentage weed reduction

Treatments reduced weed density differently based on their types (Table 1). All integrated treatments showed highest percentage weed reduction as compared to two times hand weeded plots. Plots treated with Round-up 36 SL, Weed knock and Herbazed each supplemented with One-time hand weeded at 40 DAS recorded 83.70, 82.12 and $82.06 \%$ percentage of reduction, respectively.

\section{Weed fresh and dry weight $\left(\mathrm{gm}^{-2}\right)$}

Analysis of the variance displayed that broad leaf; grass leaf and total fresh and dry weight $\left(\mathrm{gm}^{-2}\right)$ of weed was significantly affected $(\mathrm{p}<0.05)$ by treatments (Table 2). Supplementation of herbicides with one-time hand weeding at 40 days had shown considerable effect on weed population and reduced their weight to a significant level as compared to weedy check. Significantly the 
minimum total weed fresh weight $\left(64.7 \mathrm{gm}^{-2}\right)$ was obtained from Herbazed + One times hand weeded plots at 40 DAS. Whereas, the maximum fresh weight $\left(3991.3 \mathrm{gm}^{-2}\right)$ was from weedy check plots. This maximum fresh weight could be attributed to the free growth and development of weeds that enable them in competing for nutrient sucking from soil and other resources with less competition of maize crop as no any management practices were applied in weedy check plots throughout the seasons. These findings confirm the results of $[24,25]$, who reported maximum fresh weight of weeds in weedy check and minimum fresh weight in weed control treatments.

Significantly the maximum total weed dry weight $\left(523.7 \mathrm{gm}^{-2}\right)$ was obtained from weedy check plots. Whereas, the minimum dry weight $\left(12.3 \mathrm{gm}^{-2}\right)$ was from Herbazed + One times hand weeded at 40 DAS, followed by two times hand weeded plots $\left(15.0 \mathrm{gm}^{-}\right.$ ${ }^{2}$ ). This might be due to the reason of high weed density and infestation that was competed for nutrients which in turn leaded to weed dry matter accumulation or increments in weedy check plots. Whereas, the lowest dry matter recorded in integrated treatments could be associated to the effective and efficient weed control provided by herbicides and one times hand weeding at 40 days after sowing. The results were in accordance with [26]. They reported that dry biomass of weed from the weedy control plots was significantly greater than chemical and manual weeded plots. There was no significance difference observed among combined treatments and hand weeding plots for weed fresh and dry weight $\left(\mathrm{gm}^{-2}\right)$. However, numerical difference was observed (Table 2).

Table 2: Effect of weed management practices on weed fresh and dry weight (gm-2) at 80 DAS.

\begin{tabular}{|c|c|c|c|c|c|c|c|}
\hline \multirow{2}{*}{ Treatments } & \multicolumn{3}{|c|}{ Weeds fresh weight $\left(\mathbf{g m}^{-2}\right)$} & \multicolumn{3}{c|}{ Weeds dry weight $\left(\mathbf{g m}^{-2}\right)$} \\
\cline { 2 - 7 } & Broad Leaf & Grass Leaf & Total & Broad Leaf & Grass Leaf & Total & WCE \% \\
\hline Weedknock (2L/ha) + HW@40DAS & $75.7 \pm 8.5 \mathrm{a}$ & $46.7 \pm 6.0 \mathrm{a}$ & $122.3 \pm 10.7 \mathrm{a}$ & $16.7 \pm 3.7 \mathrm{a}$ & $20.7 \pm 3.9 \mathrm{a}$ & $37.3 \pm 5.5 \mathrm{a}$ & 92.9 \\
\hline Herbazed (2L/ha) + HW@40DAS & $58.7 \pm 7.5 \mathrm{a}$ & $6.0 \pm 1.9 \mathrm{a}$ & $64.7 \pm 7.8 \mathrm{a}$ & $10.3 \pm 3.0 \mathrm{a}$ & $2.0 \pm 1.1 \mathrm{a}$ & $12.3 \pm 3.3 \mathrm{a}$ & 97.7 \\
\hline Round-up(2L/ha) + HW@40DAS & $93.0 \pm 9.4 \mathrm{a}$ & $22.7 \pm 3.9 \mathrm{a}$ & $115.7 \pm 10.4 \mathrm{a}$ & $22.0 \pm 4.6 \mathrm{a}$ & $7.7 \pm 2.3 \mathrm{a}$ & $29.7 \pm 5.3 \mathrm{a}$ & 94.3 \\
\hline Hand weeded (2x) & $45.3 \pm 6.7 \mathrm{a}$ & $28.0 \pm 4.8 \mathrm{a}$ & $73.3 \pm 8.4 \mathrm{a}$ & $8.7 \pm 2.9 \mathrm{a}$ & $6.3 \pm 2.4 \mathrm{a}$ & $15.0 \pm 3.8 \mathrm{a}$ & 97.1 \\
\hline Weedy Check & $3571.0 \pm 57.6 \mathrm{~b}$ & $420.3 \pm 17.7 \mathrm{~b}$ & $3991.3 \pm 60.5 \mathrm{~b}$ & $408.3 \pm 19.5 \mathrm{~b}$ & $115.3 \pm 9.3 \mathrm{~b}$ & $523.7 \pm 21.8 \mathrm{~b}$ & 0 \\
\hline Cv (\%) & 27.9 & 23.9 & 31.7 & 27.9 & 22.5 & 18.6 & $*$ \\
\hline F-test (5\%) & $* *$ & $*$ & $* *$ & $* *$ & $*$ & $* *$ & \\
\hline
\end{tabular}

Means followed by the same letter within the column are not significantly different at $p<0.05$ using LSD.

Note: ${ }^{* *},{ }^{*}=$ significance difference at $(\mathrm{p}<0.01)$ and $(\mathrm{P}<0.05)$ respectively; ns = no significance difference; CV $(\%)=\mathrm{Cofficient}$ of variation; $\mathrm{F}$-test $(5 \%)=$ Probability value; Weedknock = Glyphosate 360G/L SL; Herbazed = Glyphosate; Round-up 36SL = Glyphosate 360g/l; WCE $(\%)=$ Weed control efficacy

Application of treatments increased weed control efficacy (WCE \%). The highest weed control efficacy was observed in Herbazed + One times hand weeded at 40 DAS, followed by two times hand weeded plots (97.1\%). This shown that supplementation of pre-panting herbicides with one-time hand weeding at 40 DAS improved WCE\% than two times hand weeding at 25 and 40 DAS alone; which was due to decrement in weed density and fresh weight that resulted from vigor growth of crop and high competition for resources over weeds.

\section{Maize grain yield and related parameters as affected by treatments}

Data pertains to maize grain yield and its components shown that both parameters were influenced by weed management practices. Statistically no significance difference $(P<0.05)$ was observed for parameters like, plant height $(\mathrm{cm})$, cob length (cm), number of rows per cob and thousand kernel weight (gm). However, numerical difference was observed among treatments (Table 3). Significant difference $(\mathrm{P}<0.05)$ was observed on biomass $(\mathrm{kg})$ and grain yield (Table 3 ). Significantly the highest grain yield (58.13 quintals ha-1) was achieved by application of Weed knock at 2 lt ha- ${ }^{-1}$, followed by two times hand weeding ( 56.80 quintals ha $^{-1}$ ) and Round-up 36 SL (51.89 quintals ha $^{-1}$ ). While significantly the lowest grain yield (38.95 quintals $\mathrm{ha}^{-1}$ ) was obtained from weedy check plots as compared to the rest treatments. The maximum grain yield noticed in treated plots might be due excellent weed control provided by combined application of herbicides along with one-time hand weeding, and maize crop utilized resources effectively in all growth stages in seasons. In a similar study, Megersa and Fufa [21], reported that herbicidal weed control as well as hand weeding significantly boosted the grain yield of maize.

Table 3: Effect of weed management practices on grain yield and yield attributing parameters of maize at Bako, 2016.

\begin{tabular}{|c|c|c|c|c|c|c|c|}
\hline Treatments & P. Height (cm) & A/mass (kg) & E/lgth (cm) & NR/ear & TKW (gm) & Yld/ha(qt) & YAdv (\%) \\
\hline Weedknock (2L/ha) + HW@40DAS & $321.50 \mathrm{a}$ & $5.73 \mathrm{~b}$ & $19.77 \mathrm{a}$ & $15.07 \mathrm{a}$ & $406.70 \mathrm{a}$ & $58.13 b$ & 33 \\
\hline Herbazed (2L/ha) + HW@40DAS & $323.30 \mathrm{a}$ & $5.27 \mathrm{ab}$ & $19.67 a$ & $14.93 a$ & $416.70 \mathrm{a}$ & $54.55 b$ & 28.6 \\
\hline Round-up (2L/ha) + HW@40DAS & $317.30 \mathrm{a}$ & $5.33 b$ & $19.70 \mathrm{a}$ & $14.87 \mathrm{a}$ & $380.00 \mathrm{a}$ & $51.89 \mathrm{~b}$ & 24.94 \\
\hline Hand Weeded(2x) & $327.30 \mathrm{a}$ & $4.93 \mathrm{ab}$ & $18.47 \mathrm{a}$ & $15.47 \mathrm{a}$ & $426.70 \mathrm{a}$ & $56.80 \mathrm{~b}$ & 31.43 \\
\hline Weedy check & $320.20 \mathrm{a}$ & $3.53 a$ & $17.97 a$ & $13.80 \mathrm{a}$ & $383.30 \mathrm{a}$ & $38.95 a$ & ----- \\
\hline
\end{tabular}




\section{Agricultural Research \& Technology: Open Access Journal}

\begin{tabular}{|c|c|c|c|c|c|c|c|}
\hline CV (\%) & 9.1 & 5.3 & 3.4 & 7.3 & 11.1 & 11.4 & \\
\hline F-test (5\%) & $\mathrm{ns}$ & $*$ & $\mathrm{~ns}$ & $\mathrm{~ns}$ & $\mathrm{~ns}$ & $* *$ & \\
\hline
\end{tabular}

Means followed by the same letter within the column are not significantly different at $p<0.05$ using LSD.

Note: **,${ }^{*}=$ significance difference at $(\mathrm{p}<0.01)$ and $(\mathrm{P}<0.05)$ respectively; $\mathrm{ns}=$ no significance difference; $\mathrm{Cv}(\%)=$ Cofficient of variation; F-test $(5 \%)=$ Probability value; P. height $(\mathrm{cm})=$ Plant height; E/lgth $(\mathrm{cm})=$ Ear length; NR/ear $=$ Number of rows per ear; TKW $(\mathrm{gm})=$ Thousand kernel weight; A/mass $(\mathrm{Kg})=$ Above ground biomass $(\mathrm{Kg}) ; \mathrm{Yld} / \mathrm{ha}(\mathrm{qt})=$ Yield per hectare; YAdv $(\%)=$ Yield advantage; Weedknock $=\mathrm{Glyphosate} 360 \mathrm{G} / \mathrm{L}$

SL; Herbazed = Glyphosate; Round-up 36SL = Glyphosate 360g/l

Supplementation of Weed knock, Herbazed and Round-up 36 SL with One times hand weeding were resulted in yield advantage of maize grain of about $33.00,28.60$ and $24.94 \%$, respectively. Similarly, two times hand weeded plots were achieved yield advantage (31.43\%) over weedy check plots. This could be attributed to increment in grain yield that was resulted from less weed density and dry weight achieved by effective and efficient weed control of treatments. This result is in accordance with Blackshaw et al. [10]; [27], who reported that crop yield loss could be caused in high extent by increase in the weed biomass, weed density and weed species.

\section{Conclusion}

From this study, it could be concluded that weeds menace significant yield losses of maize showing weed management as mandatory to attain potential yield. All treatments increased grain yield of maize over weedy plots there by reducing weed infestation. Among integrated options, Weed knock at 2 lt ha-1 + HW@ 40 DAS provided the highest yield (58.13qt ha ${ }^{-1}$ ) with $33.00 \%$ more grain yield than weedy check; having statistical similarity with the rest of treatments.

Thus, spraying of herbicides (Weed knock, Herbazed and Round-up) at the rate of 2 litres/ha by mixing with 200L of water at 15-18 days before planting and supplementing with one-time hand weeding at 40 days after sowing (40DAS) is found to be effective weed control option in maize at study area and similar agro-ecology.

\section{Acknowledgement}

The authors thank the Oromia Agricultural Research Institute (OARI) for their financial support. We also express our thanks to the Bako Agricultural Research Center (BARC) for Providing vehicle and facilities during this work.

\section{Conflict of Interest}

The authors declare that there is no conflict of interests concerning the publication of this paper.

\section{References}

1. Tesfa Bogale, Tolessa Debele, Setegn Gebeyehu, Tamado Tana, Negash Geleta, et al. (2002) Development of appropriate cropping systems for various maize producing regions of Ethiopia. In Enhancing the Contribution on of Maize to Food Security in $2^{\text {nd }}$ National Workshop of Ethiopia. 12-16 November. Addis Ababa, Ethiopia. EARO and CIMMYT, pp. 61-63.

2. Duke SO (2012) Why have no new herbicide modes of action appeared in recent years? Pest Manag Sci 68(4): 505-512.

3. Chikoye D, Udensi UE, Lum AF (2005) Evaluation of a new formulation of atrazine and metolachlor mixture for weed control in maize in Nigeria. Crop protection 24(11): 1016-1020.

4. Abate T, Shiferae B, Menkir A, Wegary D, Kebede Y, et al. (2015) Factors that transformed maize productivity in Ethiopia. Food security 7(5): 965-981.

5. Dawit A, Wilfred M, Nigussie M, Spielman DJ (2008) The maize seed system in Ethiopia challenges and opportunities in drought prone areas. Afr J Agric Res 3(4): 305-314.

6. CIMMYT, IITA (2011) Maize: Global Alliance for Improving Food Security and the Livelihoods of the Resource-Poor in the Developing World | CGIAR Fund. pp. 184.

7. Swanton CJ, Murphy SD (1996) Weed science beyond the weeds: the role of integrated weed management (IWM) in agro ecosystem health. Weed Sci 44(2): 437-445.

8. Skrzypczak G, Pudelko J, Blecharezyk A (2002) Split application of herbicides in maize \& weed control efficacy. Prog Plant Prot 42: 519521.

9. Heap I (2012) International survey of herbicide resistant weeds.

10. Blackshaw RE, Lemerle D, Mailer R, Young KR (2002) Influence of wild radish on yield and quality of canola. Weed Sci 50(3): 334-349.

11. Knezevic SZ, Evans SP, Blankenship EE, Van Acker RC, Lindquist JL (2002) Critical period of weed control: the concept and data analysis. Weed Sci 50: 773-786.

12. Shakoor A, Naeem M, Ahmad CO (1986) Efficacy of different herbicides for control of weeds in maize. Pak J Agric 7(4): 264-269.

13. Mrabet R (2013) No-Till Research Rainfed Areas in Morocco. KASSA-2007.

14. Yenish JP, Doll JD, Buhler DD (1992) Effects of tillage on vertical distribution and viability of weed seed in soil. Weed Sci 40(3): 429-433.

15. Panda SC (2010) Crop Management and Integrated Farming. Agrobios, India.

16. Jeffrey L Gunsolus (1999) Comparing weed control efficacy of different herbicide. Indian journal of weed science.

17. Khan MA, Marwat KB, Khan N, Khan IA (2003) Efficacy of different herbicides on the yield and yield components of maize. Asian J Plant Sci 2(3): 300-304.

18. Duraisamy Ravisankar, Chinnagoundar Chinnusamy, Purushothaman Muthukrishnan (2013) Influence of Post Emergence Application of Glyphosate on Weed Control Efficiency and Yield of Transgenic Maize. American Journal of Plant Sciences 4(8): 1562-1567.

19. Doss CR, Mwangi W, Verkuijl H, de Groote H (2003) Adoption of maize and wheat technologies in eastern Africa: a synthesis of the findings of 22 case studies. Economic working paper, p. 1-32.

20. Cruz ED, Moody K, Ramos MBD (1986) Reducing variability in sampling weeds in transplant aman rice (Oryza sativa L.). Philippines J Weed Sci 13: $56-59$.

21. Megersa K and Fufa A (2017) Efficacy of Pre-emergence Herbicides for the Control of Major Weeds in Maize (Zea mays L.) at Bako, Western Oromia, Ethiopia. American Journal of Agriculture and Forestry 5(5): 173-180. 
22. Wylie P (2008) High profit farming in Northern Australia. Grains Research and Development Corporation, Barton, ACT, Australia; p. $1-16$.

23. Tadious T, Bogale T (1994) Effect of different weed management methods on grain yield of maize in western Ethiopia. CIMMYT, Mexico. pp. 223-228.

24. Hafeez Ullah (2000) Effect of different sowing and weed control methods on the performance of sunflower. M. Sc (Hons), Dept. Agronomy, Thesis, Agric. Univ. Peshawar, Pakistan.
25. Morris ML (2001) Assessing the Benefits of International Maize Breeding. In: Pingali PL (Ed.), Research: An overview Of Global Maize impact study.

26. Sawant AC, Jadhav SN (1985) Efficiency of different herbicides for weed control in transplanted rice in Konkan. Indian J Weed Sci 17(3): 35-39.

27. Swanton CJ, Weise SF (1991) Integrated weed management: the rationale and approach. Weed Technol 5(3): 657-663.

\section{Your next submission with Juniper Publishers will reach you the below assets}

- Quality Editorial service

- Swift Peer Review

- Reprints availability

- E-prints Service

- Manuscript Podcast for convenient understanding

- Global attainment for your research

- Manuscript accessibility in different formats

( Pdf, E-pub, Full Text, Audio)

- Unceasing customer service

Track the below URL for one-step submission https://juniperpublishers.com/online-submission.php 